\title{
PROGRESSIVE NATURE OF SOCIAL AND ECONOMIC RIGHTS IN KeNYA: A DELAYEd PROMISE?
}

\author{
Jennifer Gitiri* \\ Office of the Attorney General \& Department of Justice, Nairobi, Kenya \\ Jennifer.Gitiri@ag.go.ke
}

Received: 1 June 2019 | Revised: 14 April 2020 | Accepted: 30 April 2020

\begin{abstract}
This paper evaluates the steps taken towards the progressive realization of social and economic rights (SER) in Kenya. It aims to provide a better understanding of SER and the obligations of the state under international, regional, and national law. It further elucidates the components of progressive realization. Additionally, it identifies the guiding principles of measuring progressive realization and recommendations to develop tools that would monitor progressive realization. Recognition of SER faces many challenges as they are considered as second class rights that are not equal to civil and political rights considered as first-generation rights. The most enduring challenge for SER is that it interferes with the concept of the separation of powers and the political question doctrine by enabling courts to interfere in matters considered to be under the purview of the legislative and executive branch. The paper uses a desktop review of international, regional, and national legal instruments as well as comparative evaluation of SER jurisprudence from a host of jurisdictions. The concept of progressive realization is a goal in the ICSECR, Kenya's Constitution, and other Constitutions with the implication that SER would be implemented over a period of time. Jurisprudence from other jurisdictions is evaluated to determine the lessons learned by Kenya. The paper demonstrates that progressive realization and implementation of SER are still work in progress before they are finally anchored into mainstream human rights, just like political and civic rights.
\end{abstract}

Jennifer Gitiri is an Advocate of the High Court of Kenya and works as a Senior State Counsel at the Office of the Attorney-General and Department of Justice. 
In conclusion, progressive realization of SER imports an immediate obligation by Kenya having ratified the three human right bodies (ICSECR, UNCRC, and CRPWD) pursuant to Article 2(5)(6) of the Constitution to expeditiously move towards the realization of SER. There is a further presumption that the country would refrain from retrogressive measures and instead adopt the minimum content approach in the implementation of SER.

Keywords: Constitutional Court, Progressive Realization, Social and Economic Rights.

\section{INTRODUCTION}

The purpose of this paper is to evaluate how the concept of progressive realization has been used as a tool for the enforcement of social and economic rights (SER) in Kenya. This is done by providing a background to SER in general and Kenya in particular. The qualitative research used a desktop review of published scholarly literature as well as a case study method. Reliance on jurisprudence from South Africa has been made due to the great strides made in that country in the enforcement of SER. The article examines the influence of the International Covenant on Social, Economic, and Cultural Rights (ICSECR) in the development of the concept of progressive realization globally before narrowing down to Africa. However, the focus of the study would be on Kenya and how jurisprudence from the rest of the world has influenced adjudication of SER in Kenya, the challenges in the enforcement of SER, remedies and its monitoring mechanisms.

Progressive realization of SER is a standard adopted by States in response to popular demands in Constitution making, seeking a SER vision, overcoming historical injustices, post conflict situations, and affirmative action. ${ }^{1}$ It further describes the central theme in state parties' obligation to the enforcement of SER in the international human rights treaties encapsulated in Article 2 of ICSECR, ${ }^{2}$ Article 4 of UNCRC, ${ }^{3}$ and Article 4 of CRPWD. ${ }^{4}$ As noted by the High Court of

\footnotetext{
Dawood Ahmed and Elliot Bulmer, Social and Economic Rights International IDEA Constitution-Building Primer 9, $2^{\text {nd }} E d$ (Stockholm: International Institute for Democracy and Electoral Assistance, 2017), $12-14$. International Covenant on Economic, Social and Cultural Rights (ICESCR), UNTS 993, entered into force 3 January 1976. UNTS, "UN Convention on the Rights of the Child 1989," ( UNTS 1577, entry into force 2 September 1990). UNTS, "Convention on the Rights of Persons with Disabilities 2006" (Volume 2515, entry into force 3 May 2008).
} 
Kenya in the case of "The Attorney General and two others v John Kabui Mwai and Others."

The inclusion of economic, social and cultural rights in the Constitution is aimed at advancing the socioeconomic needs of the people of Kenya, including those who are poor, in order to uplift their human dignity. The protection of these rights is an indication of the fact that, the Constitution's transformative agenda looks beyond merely guaranteeing abstract equality. There is a commitment to transform Kenya from a society based on socioeconomic deprivation to one based on equal and equitable distribution of resources. This is borne out by Articles 6(3) and 10(2)(b). ${ }^{5}$

This is an obligation to take appropriate measures towards the realization of economic, social, and cultural rights to the maximum of available resources. ${ }^{6}$ The reference to resource availability reflects a recognition that the realization of these rights can be hampered by a lack of resources and can be achieved only over a period of time. Equally, it means that a State's compliance with its obligation to take appropriate measures is assessed in the light of available financial resources. ${ }^{7}$ Many national constitutions now allow for the progressive realization of economic, social and cultural rights.

Kenya passed a transformative Constitution in 2010 that prioritized its people in the Article 1 as being sovereign. The empowerment of the vulnerable and the marginalized individuals was one of its greatest promises expounded in Article 43 on social and economic rights. The design of this article is to enable those at the bottom to access socioeconomic rights they were denied for a long time. Moreover, it was meant to bring equality by elevating the enforcement of SER to the same status as civil and political rights through the removal of the second class status of SER. The achievement of empowerment rights was to be realized progressively in Article 21(2) of the Constitution. However, this promise has encountered numerous challenges inherent in the enforcement of SER like limited resources, balancing the political question doctrine, what would be reasonable and proportional in the enforcement of SER, and the establishment of the minimum core content of the right in question.

High Court of Kenya at Nairobi, Petition No. 15 of 2011 at 6.

ICESCR, Article 2(1); CRC, Article 4; CRPD, Article 4(2).

ESCR General comment 3, Article 2, par.1 (General Commentaries). 


\section{BACKGROUND}

The foundation of progressive realization of SER is the Universal Declaration of Human Rights (UDHR), ${ }^{8}$ which recognized a universal regime of human rights and enforcement in Article 22-27 that are inherent, indivisible, and inalienable. Though not binding, the UDHR is considered as forming part of customary international law (erga omnes) through recognition in treaties such as the International Covenant on Social, Economic and Cultural Rights (ICSECR), United Nations Convention on the Rights of the Child (UNCRC), Convention on the Elimination of Discrimination Against Women (CEDAW) ${ }^{9}$ and the Convention on the Rights of Persons with Disabilities (CRPWD). SER is also codified in regional legal instruments like the European Social Charter of 1996, the Protocol of San Salvador of 1988 in America, and the African Charter on Human and Peoples Rights (ACHPR) of $1981 .{ }^{10}$ Similarly, SER has been codified in the Constitutions of many states like Brazil, Kenya, and South Africa.

The western concept of human rights is made in reference to civil and political rights as occupying the first generation rights. First-generation rights are anchored by the International Covenant on Civil and Political Rights (ICCPR)." Thus SER is considered second-generation rights because they require certain qualifications before implementation, such as progressive realization ${ }^{12}$ Second generation rights are protected by ICESCR. Dr. Willy Mutunga, the former Chief Justice of Kenya, stated that the global world is accepting that the Bill of Rights ensures the correction of deficiencies in a representative democracy. Moreover, he also asserted that the enforcement of economic and social rights would ensure that society achieves equality. Global recognition of the progressive realization of SER has been problematic since the establishment of the ICSECR as a human

8 Preamble, Universal Declaration of Human Rights (UDHR) adopted 10 December 1948.

9 UNTS, "Convention on the Elimination of All Forms of Discrimination against Women 1979" (Treaty Series 1249, Entry into force 3 September 1981), https://treaties.un.org/doc/Publication/UNTS/Volume\%201249/v1249.pdf.

10 African Charter on Human and Peoples' Rights, OAU Doc. CAB/LEG/67/3 rev. 5, 21 ILM 58 (1982), ratified by 53 member States of the African Union (AU).

11 ICSECR, note 3.

12 Khule Kani Moyo, The Jurisprudence of the South African Constitutional Court on Socio-Economic Rights, in Foundation for Human Rights, Socio-economic Rights: Progressive Realisation? (Johannesburg: Foundation for Human Rights: 2016 ), 58. 
right instrument. ${ }^{13}$ The clearest illustration is the challenges experienced in recognition of SER in many jurisdictions.

The first challenge was an ideological one between the West and the East as part of the existing then conflict that manifested in the cold war between communism and democracy. The west argued that only rights existing in the ICCPR or civil and political rights were worthy of recognition because they were negative rights and did not require budgetary allocations. This was disabused in the case of Schachter $v$ Canada. ${ }^{14}$ In this case, the honorable judges of the Canadian Supreme Court of Canada opined that any costs and remedies that a court awards always come with budgetary consequences in terms of expenditure and saving of cash. Moreover, while a right can be a political or civil right, it does not mean that financial costs do not come from the decision. For instance, in Askov, the judges dealt with a case that involved the right to fair trial comprising political and civil rights. In their opinion, it was stated that the state should conduct criminal trials expeditiously. ${ }^{15}$ Illustrating that, the decision would lead to more courthouses and judicial staff like prosecutors and judges, all of which have budgetary implications. Nevertheless, the Court did not rule on the means through which the state would meet this need since the executive has the prerogative to meet the requirement. Thus, this similar approach is taken when dealing with economic and social rights.

The West also thought that enforcement of the SER would be on an international scale and not subject to national implementation as part of the spread of socialist ideology. ${ }^{16}$ Beyond the availability of resources, other challenges to the realization of SER were fears that the doctrine of separation powers may be violated as courts were capable of intruding into matters of policy and executive functions in particular and interfere with the political doctrine question. In other respect, it is due to a lack of guiding principles that SER is considered not precise.

\footnotetext{
${ }^{13}$ T Kondo, "Socio-Economic Rights in Zimbabwe: Trends and Emerging Jurisprudence," African Human Rights Law Journal 17 (2017): 163-193.

14 Schachter v Canada [1992] 2 SCR 679, [63].

$15 \mathrm{R} v$ Askov [1990] 2 SCR 1199.

${ }_{16} \mathrm{R}$ v Askov [1990] 2 SCR 1199, 23.
} 
The argument by the socialist East was that political and civil rights could not be enjoyed in an environment of inequality and rampant poverty. After overcoming the initial conflict, western nations were cautious against binding themselves to ICSECR, despite this agreement being enforced in 1976 as secondgeneration rights.

The first-generation rights comprised political and civil rights under ICCPR promoted by western countries. The most enduring assumption by western constitutions has been that negative rights are protected (political and civil) are sufficient since liberty assumes the existence of SER ${ }^{17}$ Yet millions of individuals in the western world live below the poverty line and would need the protection of ICSECR.

For most jurisdictions, the concept of progressive realization of SER is still a novel one in most legal discourse. This is despite many jurisdictions recognizing this class of rights but pulling back when faced with enforcement. For example, though India and Ireland recognize socioeconomic rights, they have declared them non-enforceable. ${ }^{18}$ The Canadian Charter that provided a very helpful interpretation of human rights was quiet in the context of SER. Similarly, the common law was silent, mainly constrained by the formal and technical reasoning that is hostile to the developing jurisprudence in SER. In Africa, the endurance success in the implementation of SER is attributed to the Constitution of South Africa of 1996 as well as Kenya's 2010 Constitution and especially the accompanying innovative interpretation that has filled the void.

SER comprises the whole range of rights contained in the Bill of Rights or Article 43 of the Constitution of Kenya consisting of the following: the right to health care, reproductive health care, accessible and adequate housing, reasonable standards of sanitation; adequate food of acceptable quality; clean and safe water in adequate quantities, to social security; and the right to education.

\footnotetext{
${ }_{17}$ Brian Ray, "Engagement's Possibilities and Limits as a Socioeconomic Rights Remedy," Washington University Global Studies Law Review 9, (2010): 399.

18 Moyo, The Jurisprudence of, 23.
} 
Figure 1:

Architecture of Social, Economic Rights in Kenya

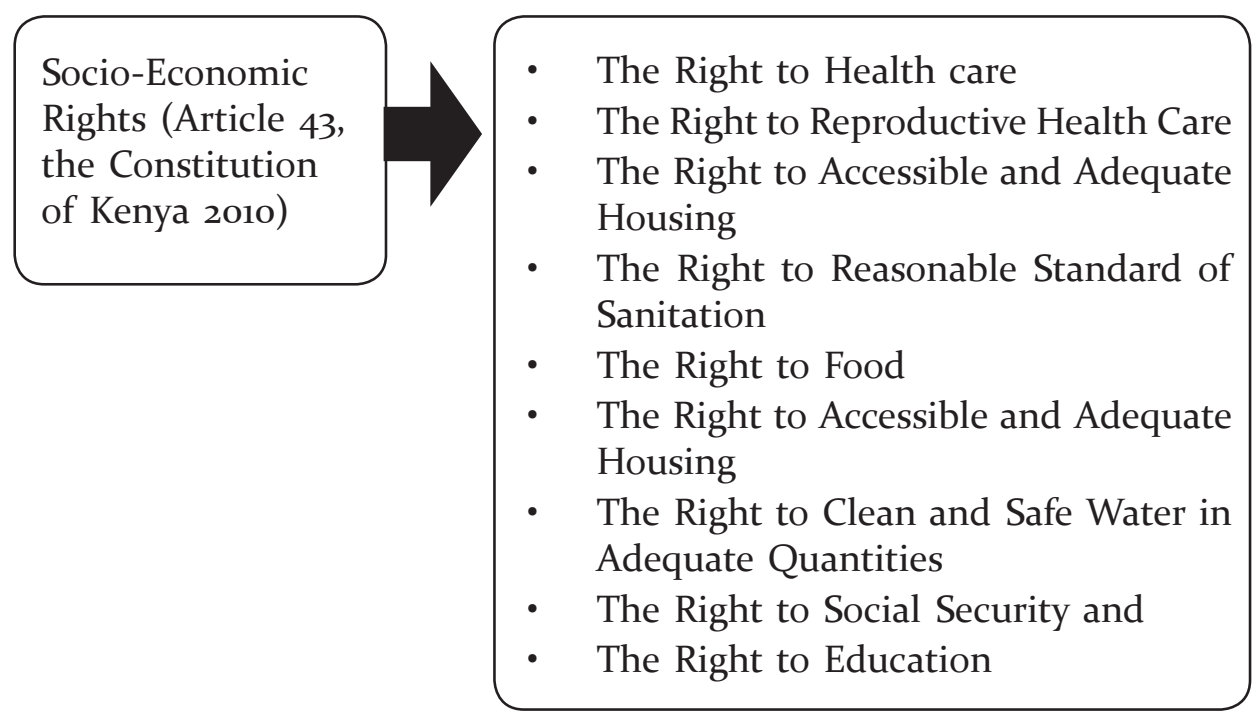

This research is qualitative in nature and used the desktop review of international, regional and domestic legal instruments such as the General Commentary Number 3, ICSECR, UDHR, ACHPR, Kenya's 2010 Constitution and the Constitution of South Africa. This was supplemented with SER jurisprudence emanating from the High Court of Kenya and the Constitutional Court of South Africa, which have been relied on by courts in Kenya. This is in addition to a review of scholarly writings by eminent authors and electronic media.

Case study and comparative analysis of SER jurisprudence from other jurisdictions, especially South Africa provide illustrations of how the South African Constitutional Court (SACC) has addressed the progressive realization of SER. Decisions of the SACC have been used to the extent that they have helped the advancement SER in Kenya. 


\section{THE CONCEPT OF PROGRESSIVE REALIZATION}

The concept of progressive realization is new in most legal systems. This is because civil and political rights did not require qualifications like SER before implementation. In many jurisdictions, the justiciability of SER is either not accepted, underdeveloped, or just beginning to emerge. ${ }^{9}$ The realization of SER is a challenging task in international human rights law because the rights are said to be vague and imprecise. Thus, a standard was created known as progressive realization, which was adopted in regional, domestic, and international law. ${ }^{20}$ Article 2(1) of ICESCR, which requires States to ensure that SER is fully realized. CESCR stated that to progressively realize these rights, states should recognize that these rights cannot be achieved within a short duration of time. Truly, the Constitution of South Africa, especially Sections 26, 27, and 36 and Article 21(2) of the Kenyan Constitution are similar and states that the State should take a policy, legislative and other steps that include ensuring standards are set to progressively realize the achievement of rights stated in Article 43. However, because there are variable financial capabilities among states, there should be flexibility in meeting the differences. This is achieved through obligations of protecting, respecting, promoting, observing, and fulfilling these rights. ${ }^{21}$

Furthermore, the progressive realization of SER highlights the complexity involved in the enforcement of SER. It depicts the resource dependent nature of these obligations when it comes to SER. ${ }^{22}$ The gist of the concept is that rights would not be realized immediately but rather that needs that are basic are met. The State plays a huge role in taking necessary steps to ensure the achievement of SER. It would amount to facilitation of access through the removal of legal, administrative, operational and financial constrains that act as barriers towards the realization of SER. ${ }^{23}$ The concept can be used by a claimant to establish the

19 S Liebenberg, Socio-economic Rights: Adjudication under a Transformative Constitution (Pretoria: Juta and Company Ltd, 2010), 191.

20 The East African Centre for Human Rights, A compendium on economic and social rights cases under the Constitution of Kenya 2010 (Nairobi: EACHR, 2015), 6.

${ }_{21}$ David Landau, "The Reality of Social Rights Enforcement," Harvard International Law Journal 53, no. 1 (2012): 190-247.

22 Moyo, The Jurisprudence of, 58.

23 Liebenberg, Socio-economic, 129. 
extent of unreasonableness by the state failing to ensure the full realization of SER. ${ }^{24}$ It should therefore be read in the context of the objectives of CESCR as articulated in the case of Grootboom that in the realization of rights, there should be a full justification and careful consideration when it comes to retrogressive measures to fully utilize available resources". ${ }^{25}$ Moreover, it would mean that the definition of progressive realization is contextual, as illustrated by the Courts in South Africa, that have given an interpretation of the meaning of progressive realization. They state that it refers to the ripping into pieces of administrative, financial, operational, and legal obstacles that may hinder access to these rights and their expansion to a larger population of individuals. ${ }^{26}$ For instance, in Grootboom, the economic and social rights that were always violated through discrimination by the apartheid system like the right to access to water, food, housing, health, sanitation, and education. ${ }^{27}$

\subsection{Progressive Realization in Europe}

The initial ideological differences between the East and the West affected the realization of SER in Europe. This was shown when two international treaties were created in 1950, like the European Convention on Human Rights in 1950.28 However, since it was not enough to protect rights, the European Social Charter was signed in Turin in 1961..$^{29}$ This was meant to ensure that Europe achieved the minimum required standards in education, health, housing, social protection, non-discrimination, and employment. This allowed states to choose economic and social rights to guarantee through a reporting system that traces whether states are living up to the standards and obligations. ${ }^{\circ}$ However, the European Charter of Human Rights had no single entitlements for any arising complaints if an infringement occurred in States.

\footnotetext{
24 I Merali \& V Oosterveld, Giving meaning to Economic, Social and Cultural Rights (Philadelphia: University of Pennsylvania Press, 2011), 1.

25 Grootboom, para. 45, citing CESCR General Comment No. 3 (1990) para. 9.

26 Grootboom, para. 45.

92. CESCR General Comment 3 (1990) para. 9.

93. Grootboom, para. 45.

${ }_{27}$ Natasha G Menell, "Judicial Enforcement of Socioeconomic Rights: A Comparison Between Transformative Projects in India and South Africa," Cornell International Law Journal 49 (2016): 724.

28 T. Stein, "Constitutional Socio-economic Rights and International Law:You are not Alone," PER/PELJ 16, no. 1 (2013).

29 European Social Charter (1961) (Hereinafter ESC).

30 ESC, Article 20, Part IV.
} 
Moreover, the treaty was revised in $1996 .^{31}$ This enabled airing of complaints, with trade unions being able to highlight issues..$^{32}$ The European Union took the step of improving social protections in Europe with Title IV of the EU Charter on Human Rights included a solidarity name in December 2009 to ensure protections of SER through a legal framework.

\subsection{America and Progressive Realization of Social Economic Rights}

The Inter-American system that protects SER and the South African Charter is similar in their approach to the realization of SER in a progressive manner. However, the American mechanism is thought to be limited in terms of their effectiveness in the legal remedies that they offer. ${ }^{33}$ The western system makes a distinction between categories that human rights are classified since every state has its own cautions that legally bind them to grant SER. For instance, the Brazilian system is such that the judiciary has adopted assertive stances when upholding SER. As opposed to South Africa, the Brazilian Courts have always determined the extent of SER where the state can be ordered to provide services and goods to the petitioner. ${ }^{34}$ The United States was among the last nations to sign the ICSECR in 2007 without ratification.

\subsection{Progressive Realization in Africa}

A vast majority of African states (90\%) have ratified the ICSECR. ${ }^{35}$ The ICSECR influenced the drafting of the African Charter in 1981 for more than 15 years since the adoption of ICSECR. However, the protections under the charter are narrower than those of the ICSECR. The influence of the two legal instruments on constitutional provisions in Africa is limited since many states have not translated them into constitutional provisions due to a lack of political will. ${ }^{36}$ Few African states have shown a lot of innovation in the adjudication of

${ }^{31}$ Additional Protocol to the European Social Charter Providing for a System of Collective Complaints (1995).

32 Menell, "Judicial Enforcement of," 726.

33 Stein, "Constitutional Socio-economic," 12.

34 Octavio Luiz Motta Ferraz, "Harming the Poor Through Social Rights Litigation: Lessons from Brazil," Texas Law Review 89 (2011): 645 .

35 M. Ssenyonjo, "The Influence of the International Covenant on Economic, Social and Cultural Rights in Africa," Neth Int Law Rev 64, (2017): 259-289.

${ }_{36}$ Ssenyonjo, "The Influence of," 267. 
SER, perhaps borne out of decades of rampant poverty, corruption, conflict, and oppression. The best examples are Kenya and South Africa. Pursuant to Article 2(5)(6), the ICSECR forms part of Kenya's domestic legal system, having ratified it in 1992. In South Africa, for instance, a progressive realization has been deployed mainly to enforce SER to housing, health care, water, and sanitation. ${ }^{37}$ Thus apart from Kenya and South Africa, where domestic courts have adopted ICSECR interpretation in the implementation of SER, the great majority of African states ${ }^{38}$ are reluctant to enforce SER despite ratifying the ICESCR and ACHPR. These states find the enforcement of SER non-justiciable directives as principles of state policy.

\section{ENFORCEMENT OF SOCIAL ECONOMIC RIGHTS IN KENYA}

Since the 2010 Constitution was promulgated, the enforcement of SER by the Kenyan courts has made a lot of progress. Other than using progressive realization to enforce housing rights as in the Muthurwa case ${ }^{39}$ and other SER, Kenya has gone further and used it to advance the right to equality and healthcare, non-discrimination as well as affirmative action. But as a preliminary matter, the courts had to deal with the challenges of locus standi and award of costs that stood in the way of progressive realization of SER in Kenya. Other challenges like internal and external limitations envisaged in Article 24 of the Constitution act as claw back on the realization of SER.

\subsection{The Challenge of Locus Standi}

Before 2010, only the Attorney-General had the locus standi to bring legal action on behalf of the public. This curtailed any action that would relieve the suffering of members of the public since the Attorney-General could always defend the State. The Article 22 and 258 of the 2010 Constitution changed all that by expanding standing to members of the public who had an interest

37 Constitution of South Africa, 1994, Section 26,27 and 36.

${ }_{38}$ Such as the Constitutions of Nigeria (1999), Lesotho (1993), Sierra Leone (1991), Ghana (1992), Ethiopia (1994), Uganda (1995) and the Gambia (1996).

39 Satrose Ayuma and 11 Others v. The Registered Trustees of the Kenya Railways Staff Retirement Benefits Scheme and 2 Others. High Court of Kenya, Petition No. 65 of 2010, para 54 (Decision of August 2013) (Hereinafter Muthurwa Case). 
in any matter violated fundamental rights, and freedoms could begin legal proceedings on behalf of the people. This was affirmed in the case of the Republic $v$ Independent Electoral and Boundaries Commission \& Another, where the High Court highlighted that "the Judiciary acts as the repository and watchdog and is enjoined to enforce and defend the Constitution." ${ }^{40}$ Rules on locus standi have further been entrenched by Article 22(3), which requires the Chief Justice to enforce and make the laws that ensure that constitutional rights in the Constitution are adjudicated. Thus, it would enable vulnerable people whose SER are routinely violated access to justice. This has been implemented by the Chief Justice through the establishment of the Constitution's Practice and Procedure Rules of $2013^{41}$ with the aim of facilitating access to justice to all in accordance with Article 22 of the Constitution of Kenya.

\subsection{Limitation of SER}

A proper understanding of SER is not complete without investigating internal and external limitations of human rights and SER in particular. SER is subject to further limitations in international and national law, giving the impression that implementation of the rights is not absolute. This is despite clear legal provisions on the implementation of SER in international, ${ }^{42}$ regional ${ }^{43}$, and national law. These instruments have internal mechanisms for the limitation of human rights. The clearest indication that the progressive realization of SER is limited in international law is found in Article 4 of the ICSECR, which states as follows:

The States Parties to the present Covenant recognize that, in the enjoyment of those rights provided by the State in conformity with the present Covenant, the State may subject such rights only to such limitations as are determined by law only in so far as this may be compatible with the nature of these rights and solely for the purpose of promoting the general welfare in a democratic society. ${ }^{44}$

40 Ex-Parte Councillor Eliot Lidubwi Kihusa\& 5 Others [2012] eKLR, para 78.

$4^{1}$ The Constitution of Kenya (Protection of Fundamental Freedoms) Practice and Procedure Rules, 2013, Legislative Supplement No. 47, 28 June 2013, Kenya Gazette Supplement No. 95, Rule 3(2).

42 The ICESCR Assented to by Kenya on 1 May 1972; The CRC Ratified by Kenya on 30 July 1990; The CEDAW Assented to by Kenya on 9 March 1984; The UNCRPD. Signed by Kenya on 30 March 2007.

43 ACHPR; The Protocol on the Rights of Women in Africa (2003). Ratified by Kenya on 6 October 2010; The African Charter on the Rights and Welfare of the Child (1990). Ratified by Kenya on 25 July 2000.

44 ICSECR, Article 4. 
This provision has been adopted by Article 24 of the Kenya's constitution to the effect that since SER fall into the category of human rights that can be derogated by the state, such rights can be limited so long as it is reasonable and justifiable in an open and democratic society based on human dignity, equality, and freedom. The effect of this provision is to hamper the realization of SER in Kenya.

\section{CHARACTERISTICS OF SER IN KENYA}

\subsection{Award of Costs in SER}

Other than widening standing, the courts in Kenya have used their discretion and have been lenient with respect to the award of costs in matters dealing with SER, particularly where public interest litigation is concerned. In John Harun Mwau \& 3 Others v. Attorney General \& 2 Others the Court, ${ }^{45}$ the court opined that:

The intent of Articles 22 and 23 of the Constitution is that persons should have free and unhindered access to this court for the enforcement of their fundamental rights and freedoms. Similarly, Article 258 allows any person to institute proceedings claiming the Constitution has been violated or is threatened. The imposition of costs would constitute a deterrent and would have a chilling effect on the enforcement of the Bill of Rights. ${ }^{46}$

Judicial discretion in the award of costs has further been strengthened by the Mutunga Rules that have facilitated access to justice. ${ }^{47}$ Therefore, citizens have been emboldened into entrenching SER, which could happen in cases where the plaintiffs can count on "litigation-oriented organizations that can support a prolonged and strategically planned litigation campaign; extensive charitable or State funding; and public interest or rights oriented lawyers who can do the legal work." 48 The progressive realization has extended into protecting the violation of non-discrimination and equality.

High Court Petition No. 123 of 2011.

lbid., para 179.

47 Mutunga Rules, Rule 26.

48 A. Cahill-Ripley and D. Hendrick, D, Economic, Social and Cultural Rights and Sustaining Peace: An Introduction (London: Friedrich-Ebert-Stiftung, 2018), 15. 


\subsection{Advancing Non-discrimination and Equality}

The progressive realization of rights has been used in Kenya to advance non-discrimination and equality and the balancing of competing interests. The Courts in Kenya have argued that all rights are inter-related and independent. Consequently, they have adopted a holistic approach to the interpretation of the rule of the constitutional completeness, paramountcy, harmony, exhaustiveness of the Constitution, and its self-sufficiency in particular. ${ }^{49}$ In the Federation of Women Lawyers Kenya and Others $v$ The Attorney General and Others, ${ }^{50}$ the court stated that:

It is important to understand the basics which are that the rights contained in the Bill of Rights are interrelated and mutually supportive. The specific constitutional rights must not be seen in isolation but must be understood in their textual settings and in their social and historical context. ${ }^{1}$

In addressing itself to matters of standing, costs, and indivisibility of rights, the Kenyan courts have moved into unchartered areas of affirmative action. The Attorney-General, in particular, has used progressive realization as a defense to petitions against State violation of non-discrimination and equality in the advancement of affirmative action..$^{52}$ The petitioners challenged the composition of the Supreme Court, where the petitioners argued that affirmative action, as provided in Article $27(8)$, was not subject to liberal realization as contended by the Attorney-General but rather for immediate implementation. The honorable Court aligned with the arguments of the Attorney-General, who stated that affirmative action was subject to progressive realization pending formulation of policy and legislative measures. This decision represented a major set-back in matters of gender equality and non-discrimination.

This impression was corrected in the Centre for Rights Education and Awareness (CREAW) and eight others $v$ Attorney General \& another. ${ }^{53}$ This petition

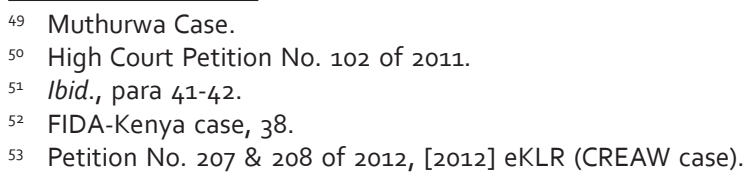


challenged the appointment of County Commissioners on the ground; inter alia, that the President breached Articles 10 and 27(8) of the Constitution when he appointed only ten women and 37 men to occupy the 47 positions. ${ }^{54}$ The court rightfully put progressive realization in the context that only Article 21(2) of the Constitution (on progressive realization) applied to the rights contained in Article 43 of the Constitution (SER), and not all the rights in the Bill of Rights. 55 In this regard, the Court found that:

The Constitution is thus very clear on what rights are subject to the progressive realization test-the social and economic rights to health care, education, water, housing, and sanitation. Such rights require the allocation of resources, and as is the case with similar provisions in the [ICESCR], the state's obligation is made subject to the availability of resources. Had it been the intention to make the principle that is not more than two thirds of elective and appointive positions should be of the same gender subject to progressive realization, nothing would have been easier than for the Constitution to make this specific provision.

However, the Supreme Court of Kenya Advisory Opinion, ${ }^{56}$ in their opinion on the two-thirds gender rule, was another setback in the advancement of rights to non-discrimination and equality. In the advisory, Attorney-General requested the Court to give their opinion on the two-thirds gender rule. The majority opinion in the Court was of the view that affirmative action was subject to progressive realization by using the word aspirational.

One of the major criticisms of the developments in Kenya is that despite these innovations, litigation is confrontational in meaning. ${ }^{57}$ A more robust approach by the courts of an inquisitorial nature would be more preferable because, for every violation that ends up in court, many others fall by the way for lack of representation. The overall and majority view is that there is no going, progress in the advancement of SER can only move forward.

\footnotetext{
CREAW case, para 11-16.

Ibid., para 47.

${ }^{56}$ In the Matter of the Principle of Gender Representation in the National Assembly and the Senate, Supreme Court of Kenya, Advisory Opinion Application 2 of 2012, para 1-2 \& 27-30.

57 Ibid at 13 .
} 


\subsection{Right to Health Care in Kenya}

Access to health care and constitutional provisions on SER and health, in particular, could not come at the right time. Since the passage of Kenya's 2010 Constitution, many litigants have gone to court in an attempt to enforce this right. The first of such a case was $P A O v . A G,{ }^{8}$ where the petition challenged the constitutionality of Sections 2 and 34 of the Anti-Counterfeit Act. The argument advanced was that the provision would have an adverse effect on access to essential medicines like generic medication for managing HIV. In the case, the petitioner's argument was that a broad interpretation counterfeit would encompass generic drugs, therefore, making it difficult to treat HIV. Further, limiting access to generic drugs would make it difficult for the poor, vulnerable, and marginalized access the right to health care.

The hallmark of achieving SER in Kenya has been public interest litigation. This was demonstrated in the Kenya Society for the Mentally Handicapped (KSMH) $v$ Attorney General and Others. ${ }^{59}$ This case was brought the best interest of the public in opposing the discrimination of mentally disabled people. In the case, the petitioners were of the view that the Respondents had discriminated against mentally disabled people denying them rights such as health, education, and financial support.

The petition failed on a technicality since the Petitioner failed to properly set their case with the judges stating that the case lacked clarity and objectivity. Therefore, the Court did not determine the matter on merit. The petitioners had failed to adduce sufficient evidence to make a legal assessment on discrimination as alleged. Moreover, the case was dismissed on a lack of particularity since they did not show the specific provisions of the constitution that were violated. The court, in coming to a determination, considered the social and economic context of HIV, stating that it remains a burdensome healthcare problem in Kenya for most families. The court stated that the patient's right to access drugs is subsumed within the broader context of access to affordable health care. The

$5^{8}$ High Court of Kenya, Petition No. 409 of 2009 (PAO case).

59 High Court Petition No. 155A of 2011 (Hereinafter Kenya Society for Mentally Handicapped case). 
court upheld the Treatment Action Campaign case, ${ }^{60}$ stated that access to drugs in the hospital was a significant part of the right to health. Therefore, failing to ensure access violates the right to health in the Constitution.

Similarly, the healthcare rights enforced in Kenya under the SER rubric requires a petitioner to demonstrate an inability to afford life-sustaining drugs. In Mathew Okwanda V Minister of Health and Medical Services $\mathcal{E} 3$ others, ${ }^{61}$ the petitioner in the case was an elderly man diagnosed with diabetes mellitus and lacked financial resources to manage the condition due to its prohibitive costs. The petitioner stated that he needed urgent medical assistance and sought legal redress to ensure that his social rights were upheld, as stated in Article 43. He also argued that he was entitled to affordable care, quality, safe, and clean water, housing, and social security in accordance with Articles 2(5) and (6) of the Constitution and relevant laws like Article 11 of the ICESCR with the state having an obligation to uphold these rights. Similar to the Kenya Society for Mentally Handicapped case, the petition failed due to its presentation in an omnibus manner. Although the court dismissed the petition, it acknowledged the obligation of the state to ensure that SER is upheld.

\section{STANDARD OF REVIEW IN SOCIAL ECONOMIC RIGHTS}

The standard of review of progressive realization of SER is pegged on the availability of financial resources, political question doctrine minimum content, and reasonableness.

\subsection{Availability of Resources}

Built into the enforcement of SER is a limitation on the accessibility to financial resources. Many Constitutions that have stipulations for SER show that depends on the available financial resources. Unlike political and civil whose realization is not pegged on the availability of financial resources, legal provisions touching on enforcement of SER in international and domestic law

\footnotetext{
60 Minister of Health and Others v Treatment Action Campaign and Others (No 1) (CCT9/02) 2002 (5) SA 703 (5 July 2002).

61 Petition 94 of 2012 Mathew Okwanda v Minister of Health and Medical Services \& 3 others [2013] Eklr.
} 
have a financial implication built into it. Critics who believe that SER is misplaced have given this reasoning prominence as an illustration as to why they should not be enforced. What is often forgotten is that all rights, including political, civil, social, or economic, require direct and indirect financial provision. ${ }^{62}$ The Courts have argued that financial availability affects the extent to which state measures can be said to be reasonable. In the case of Grootboom, which has been affirmed by Kenya courts, the judges stated that there exists a difference between means and goals. The measures must be meticulously balanced to achieve an expeditious goal and ensure the availability of resources as a significant factor in ensuring the enjoyment of SER rights. Though the courts have further argued that they have no desire in re-arranging the State's budget, it is clear some of the decisions point towards that direction. In doing so, courts are disadvantaged since they do not have full facts and evidence about the State's financial position in action being adjudicated upon.

The High Court of Kenya in Mathew Okwanda Case ${ }^{63}$ and relying on the Soobramoney case held as follows:

16. Therefore, even where rights are to be progressively achieved, the State has an obligation to show that at least it has taken some concrete measures or is taking conscious steps to actualize and protect the rights in question. The South African constitutional court in Soobramoney $v$ Minister of Health (Kwazulu Natal) 1998 (1) SA 765 (CC) interrogated the question of right to access to health care and emergency treatment. The court was called upon to determine whether the health rights in section 27 of the Constitution entitled a chronically ill man in the final stages of renal failure to an order obliging a public hospital to admit him to renal dialysis programme of the hospital. According to the guidelines for the programme the applicant was unqualified. The court in its judgment noted that the Ministry of Health had conclusively proved that there were no funds available to provide patients such as the applicant with the necessary treatment. The court also observed that if the overall health budget was substantially increased to fund all health care programs this would diminish the resources available for the State to meet other social needs. The court stated as follows; "The State has to manage its limited resources in order to address all these claims. There will be times when this requires it to adopt a holistic approach to the 
larger needs of society rather than focus on the specific needs of particular individuals within society.

This position was adopted in the John Kabui Mwai case (cited above) wherein the court observed that, 'The realisation of socioeconomic rights means the realization of the conditions of the poor and less advantaged and the beginning of a generation that is free from socioeconomic need. One of the obstacles to the realisation of this objective, however, is limited financial resources on the part of the Government. The available resources are not adequate to facilitate the immediate provision of socioeconomic goods and services to everyone on demand as individual rights. There has to be a holistic approach to providing socioeconomic goods and services that focus beyond the individual.

Therefore, the availability of resources for the fulfillment of SER remains a great concern.

\subsection{The Political Question Doctrine}

The political question doctrine is another standard the courts have to balance carefully. The dilemma for the courts in most jurisdictions is which matters belong to the courts and which ones belong to other state institutions? The political question doctrine arises in litigation and which by the implied principle of the Constitution is omitted from a final determination. ${ }^{64}$ It refers to discussing the Court's jurisdiction in a significant as the Court's foray into the policy arena. ${ }^{65}$

In the Mitu-Bell case, ${ }^{66}$ the petitioners were evicted from land they had settled in as squatters. The land belonged to the Kenya Airports Authority, and they were evicted on the grounds that it was a flight path. The case was filed at the High Court of Kenya where the court held inter alia, "That the respondents do provide, by way of affidavit, within 60 days of today, the current state policies and programs on provision of shelter and access to housing for the marginalised groups such as residents of informal and slum settlements." The Kenya Airports Authority dissatisfied with the decision appealed to the Court of Appeal which overturned the High Court decision and held as follows:

\footnotetext{
64 Bantekas.I and Oette.L, International Human Rights Law and Practice 2nd edition (Cambridge: CUP, 2016$), 13$.

65 M. Ssenyonjo, Economic, Social and Cultural Rights in International Law 2nd ed (Oxford: Hart, 2016), 3.

66 Kenya Airports Authority v Mitu-Bell Welfare Society \& 2 others [2016] eKLR.
} 
Under the political question doctrine and noting the provisions of Article 20(2) and 20 (5) (c) of the Constitution, a trial court should rarely interfere with a decision by a state organ concerning the allocation of available resources for progressive realization of socioeconomic rights solely on the basis that it would have reached a different conclusion.

Scholars have argued that courts should decline to adjudicate on matters that are outside its jurisdiction especially matters on a policy that attaches to SER. According to the separation of powers, matters of policy are within the purview of the legislature and the executive. When the courts interfere in these matters, it means that they are second-guessing the wisdom of the executive and legislature. This is exacerbated by the inability of courts to define the boundaries of their jurisdiction in relation to the political question succinctly.

\subsection{Reasonableness}

The Courts will use the test of reasonableness to examine whether adequate measures taken by the state in response to the violation of a particular SER are reasonable or not. In doing so, the court may not compare other existing measures, ones it considers what is available as being reasonable; the test for this requirement would be satisfied.

In Kenya, the High Court in the case of Federation of Women Lawyers Kenya ${ }^{67}$ opined thus:

The Government must ensure that the National and County Governments have laws, policies, programs and strategies that are adequate to meet its obligation under Article 27. The measures must establish coherent programs towards the progressive and the immediate realization of all the rights within the State's available means. The programs and the legislations must be capable of facilitating the realization of the right. The precise contours and content of the measures to be adopted are primarily a matter for the Legislature and the Executive, not for the courts. We think the measures they adopt must be reasonable, practicable and they must be able to address the long term and the short term needs of the vulnerable groups of our society.

Similarly, the High Court of Kenya in Jaffer $v$ Ministry of Justice ${ }^{68}$ relied on the Grootboom's case and held that:

${ }_{67}$ Federation of Women Lawyers Kenya (FIDA-K) \& 5 others v Attorney General \& another, Petition No. 102 of 2011. 68 Jeffer Isaak Kanu V Ministry Of Justice, National Cohesion And Constitutional Affairs \& 3 Others [2013] Eklr. 
38. The common argument as seen above is that the measures taken by the State must be reasonable. In the South African Constitutional Court case of Government of the Republic of South Africa v Grootboom 2001(1) SA $46(\mathrm{CC})$ regarding the State's responsibility on provision of socioeconomic rights the Court rendered itself thus;

"A court considering reasonableness will not enquire whether more desirable or favorable measures could have been adopted, or whether public money could have been better spent. The question would be whether the measures that have been adopted are reasonable. It is necessary to recognize that a wide range of possible measures could be adopted by the state to meet its obligations. Many of these would meet the requirements of reasonableness. Once it is shown that the measures do so, this requirement is met."

Grootboom overturned the requirement for rationality articulated in Soobromaney. This test has, however, been criticized for being insufficient in attesting to the actual content of SER and the nature of obligations they portend to protect. ${ }^{69}$ In effect, it has allowed courts to be lazy in providing for normative content in respect of SER. $7^{\circ}$ Due to this failure to provide for the core content, it is doubtful that it is still able to provide adequate protection to the poor vulnerable groups and save them from the harm that would arise without the court's assistance. ${ }^{71}$

This criticism based on two stages required in the adjudication of constitutional rights: ${ }^{72}$ The first stage involves the development of the content of the right and whether the actions of the defendant violates the right in question. The second is an inquiry into reasons for the first limitation and its proportionality.73 The reasonableness test facilitates the distinction between the two requirements. ${ }^{74}$ Similarly, in Grootboom the court simply affirmed the violation of the right to affordable housing without articulating its content as provided for in Section 26 of the South African Constitution. Moreover, the reasonableness tests a

\footnotetext{
69 Center for Economic and Social Rights, The Universal Periodic Review: A Skewed Agenda? Trends Analysis of the UPR's Coverage of Economic, Social and Cultural Rights (New York: CESR, 2016), 11.

70 Liebenberg, Socio-economic,173.

${ }^{71}$ A. Cahill-Ripley, "Challenging Neoliberalism: Making Economic and Social Rights Matter in the Peace building Agenda," in Economic and Social Rights in a Neoliberal World, ed. Frey D and MacNaughton. Gn (Cambridge: Cambridge University Press, 2018), 8.

72 Cahill-Ripley, "Challenging Neoliberalism."

73 Section $36(1)(e)$ of the Constitution. of South Africa.

74 Grootboom para. 41.
} 
perception of entitlement to goods and services, whereas it should only be a reasonable government mechanism. ${ }^{75}$

\subsection{Minimum Core Content}

The lingering question in progressive realization is the minimum right's content being adjudicated upon. The minimum core content is an approach based on General Comment 3 of 1990 of the CESCR on the nature of the obligations of States Parties under the ICESCR. The concept of minimum core content suggests the existence of degrees of the fulfillment of SER arising from a basic need to survive and the socioeconomic expectations required in the process. ${ }^{76}$ In effect, it simply suggests that certain needs are more important and therefore desire protection. The minimum content provides a standard and mirror through which progressive realization that is relativist in nature is viewed in international, regional, and domestic law. It provides States with the discretion to implement SER pursuant to the availability of financial resources. ${ }^{77}$ It, therefore, provides directions and steps only intervening when there is a pointer towards regression..$^{78}$ A failure to accommodate this concept has an effect on the justifiability of SER as its context and meaning is left for speculation. Minimum core content ensures certain obligations on states to fulfill. ${ }^{79}$ This is a minimum right strategy that points to maximum gains as a prelude to minimum gains in the context of SER. ${ }^{80}$ However, this concept has been criticized for threatening the broader goals SER since such scales are yet to be determined..$^{81}$ Additionally, insisting on minimum content only manages to direct attention towards the performance of developing countries, ${ }^{8_{2}}$ which avoids addressing those suffering similar violations in developed counties. Moreover, there is a tendency to rank claimants as an assessment of

75 Carol C Ngang, "Judicial Enforcement of Socio-Economic Rights in South Africa and the Separation of Powers Objection: The obligation to Take Other Measures," African Human Rights Law Journal 14, no. 2 (2014).

76 CESCR General Comment No. 3 (1990) para. 9.

77 ICCPR, Art. 2(1).

78 General Comment No. 3,

79 U.N. Econ. \& Soc. Council [ECOSOC], Comm. on Econ., Soc. \& Cultural Rights, "Report on the Fifth Session, Supp. No. 3, Annex III, I 10, U.N. Doc. E/1991/23" (1991, hereinafter General Comment No. 3).

80 Kondo, "Socioeconomic Rights in," 165

81 Ahmed and Bulner, Social and Economic, 13.

82 Ray, "Engagement's Possibilities and," 400. 
economic growth or defense policies are disregarded. ${ }^{83}$ Finally, at a conceptual level, it would not be fair to argue that minimum content in a country like Mali is equivalent to Canada and, if so, what would be the standard?

\subsection{Minister of Health and Others $v$ Treatment Action Campaign and Others ${ }^{84}$}

This case confirmed the reasonableness test adopted in Grootboom, which was delivered two years later. The issue, in this case, was whether the court could and should intrude on contentious matters considered bordering on state policy. The case arose out of the Department of Health, restricting to two sites out of the nine provinces for Nevirapine given to pregnant ladies who lived with HIV and were a few days or weeks from giving birth.

The Court in South Africa rejected the advanced argument that it was for the national scientific authorities and no longer for judges to prescribe drugs. The court held that it was exactly the principle of separation of powers in the Constitution that requires the judiciary to test the national policies and establish if they have departed from the State's obligation to take reasonable measures to recognize SERs.

\section{REMEDIES IN SOCIAL ECONOMIC RIGHTS}

The progressive nature of SER is evident in the remedies that are granted in case of a breach. The violations of SER like those experienced in societies emerging from conflict such as the apartheid regime are systemic and on a large scale. For that matter, monetary compensation would not be an adequate remedy. The Courts have sought innovative remedies in addressing these violations. This was borne out of necessity and the fact that in many of the suits filed, the plaintiffs or communities are poor without access to legal services and sometimes have to rely on public interest litigation (PIL) to argue their case. ${ }^{85}$ The Courts have particularly imported remedies in judicial review and administrative law into

\footnotetext{
83 Landau, "The Reality of Social," 191.

${ }^{84}$ (No 2) 2002 (5) SA 721 (CC).

85 Ibid., 63.
} 
SER, such as prohibitory and mandatory orders. Others are reporting orders, supervisory orders, and meaningful engagement to effect conduct in violation of SER.

\subsection{Prohibitory Orders}

Prohibitory and mandatory orders are orders that are commonly used in administrative law. Currently, they are being used in the context of SER purposely to compel some conduct of the state of an economic and social nature. A Prohibitory order in SER may involve a threatened interference in existing access to SER. 86

\subsection{Mandatory Orders}

Mandatory orders are granted in circumstances where the violation of a right includes failure by a State organ, or compulsory order would be given. ${ }^{87}$ Mandatory orders provide effective relief for violations SER, especially in providing benefits and services to a particular class of people in situations where it is vital and where the relief can be clearly defined. In TAC, it was clear that the court was prepared to grant this relief where a state failed to uphold its constitutional duties of a social and economic nature. It clearly showed that courts had the capacity to intrude into matters of policy, the budget that has distribution implications. ${ }^{88}$ In the same case, the court ordered the state to immediately eliminate restrictions from the provision of the drug known as Nevirapine in clinics and hospitals as well as grant and facilitate its use.

\subsection{Orders of Meaningful Engagement}

A meaningful engagement is increasingly becoming synonymous in cases that deal with evicting the poor. This is a mandatory order, for example, where there is a violation of the right to adequate housing that requires parties to engage purposely to explore solutions to the violation. ${ }^{89}$ This order is an innovation by

86 Ibid.

87 Paul O'Connell, "The Death of Socio-Economic Rights," Modern Law Review 74, no. 4 (2011): 532-554.

88 Ibid.

89 Occupiers of 51 Olivia Road, Berea Township and 197 Mainstreet, Johannesburg V City of Johannesburg \& Others (Oliver Road Case) para. 21. 
the Constitutional courts in South Africa that allows parties to continue discussing till an amicable solution can be reached in cases of evictions. It is cognizant of the vulnerable state of persons about to be evicted whose reaction would be a refusal to negotiate. Thus in such circumstances court have a duty to bring the parties together and for the state to make reasonable efforts to engage..$^{90}$ The objective of the engagement is tow fold: first, to ascertain the consequences of the eviction, and second, it is to allow the party and the authority to act in a reasonable manner when it comes to people's housing needs. In view of the court, meaningful engagement occurs where people are evicted in ways that would render them homelessness. ${ }^{91}$ In Olivia Road case, the court ordered the city of Johannesburg have meaningful engagement in conformity with the statutory duties of the municipality and the rights, duties, and fundamental freedoms of the applicant..$^{2}$

\subsection{Reporting Orders and/or Continuing Mandamus}

The Courts have also created other orders known as reporting orders that require authorities to report back to court to show progress when implementing orders. In the alternative, parties may be required to negotiate their course of action and give effect to the particular right. The role of the court in this context is supervisory, while at every stage issuing new sets of directives to regulate the engagement. This continues until such time that the violation is remedied. Parties to the suit are free to file affidavits where they are not satisfied with the progress. ${ }^{93}$

The Supreme Court of Canada, Constitutional Court of South Africa, and the Supreme Court of India have affirmed that the court has the power to issue mandatory orders and thereafter retain supervisory jurisdiction to ensure compliance in cases of violations of SERs. In the case of Minister of Health $v$ Treatment Action Campaign, the South African Constitutional Court held that “a mandamus and the exercise of supervisory jurisdiction' may be necessary to

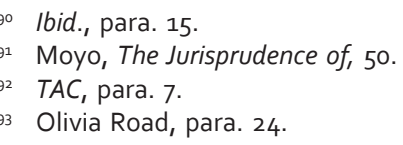


ensure an effective remedy for a breach of any constitutional right, including a socioeconomic right." 94 The Supreme Court of Canada in Doucet-Boudreau $v$ Nova Scotia ${ }^{95}$ held that a judge-after ordering that the government builds minority-language schools-can retain and exercise jurisdiction over the case by requiring the government to report back on the progress made to comply with the court orders.

In India, the Supreme Court adopted a similar approach and upheld that, "As the relief is positive and implies affirmative action, the decisions are not "one-shot" determinations but have on-going implications." ${ }^{66}$ This concept of continuing mandamus ensures that a court monitors the implementation of its orders

\subsection{Constitutional Damages}

The jurisprudence developed in South Africa in evictions and violation of the right to housing has meant that the State is a party in all applications for evictions (private or public) due to its constitutional obligation. The underlying rationale is that the State has a constitutional duty to protect its citizens from evictions and should facilitate dialogue and mediation processes. This finding was espoused in the case of the city of Johannesburg Metropolitan Municipality v Blue Moonlight Properties. ${ }^{97}$

In Kenya, the Court of Appeal in Kenya Airports Authority v Mitu-Bell Welfare Society held that:

We hasten to add that in any eviction, forcible or otherwise, adequate and reasonable notice should be given. Respect for human rights, fairness and dignity in carrying out the eviction should be observed. The constitutional and statutory provisions on fair administrative action must be adhered to..$^{8}$

With regards to damages for violation of SERs, the High Court in Kenya in JOO (also known as J M) v Attorney General held that,

94 Minister of Health v Treatment Action Campaign (No. 2) 2002 (5) SA 721 (CC).

95 Doucet-Boudreau v Nova Scotia (Minister of Education) [2003]3 SCR 3.

96 Sheela Barse v Union of India (1988) AIR 2211 (SC) at 221).

9739 (Pty) Ltd and Another 2012 (2) SA 104 (CC).

98 Kenya Airports Authority v Mitu-Bell Welfare Society \& 2 others [2016] eKLR. 
The National Government \& the County Government has failed to implement and/or monitor the standards of free maternal health care and services thus resulting in the mistreatment of the Petitioner and violation of her right to dignity, and treatment that is devoid of cruelty, inhuman and not degrading. 99 The court then awarded damages to the Petitioner as a result of the infringement of her right to health.

\section{MONITORING MECHANISMS FOR PROGRESSIVE REALIZATION}

The progressive realization is subject to a monitoring mechanism in line with international and national law. However, monitoring is a complex process carried out by various institutions, namely the state, the civil society, and democratic institutions. ${ }^{100}$ The CESCR has a monitoring system for the implementation of the ICSECR in which states regularly submit reports to the committee that monitors compliance of states. ${ }^{101}$ The Optional Protocol to the ICSECR is part of the complaints, and the inquiry process forms another tier of monitoring of compliance is achieved. The Kenya National Commission on Human Rights (KNCHR) is a statutory body tasked with monitoring compliance of human rights. The High Court is another important link in the monitoring process through its decisions. Considering that monitoring is done by a plethora of institutions, the major challenge is the construction of a simplified monitoring tool with the capacity to not only scrutinizes but make them available to the general public.

Methods used in monitoring compliance with the obligation of progressive realization include benchmarking, such as analysis of resource allocation, identifications of violations, some economic tools, and a combination of any of the above. The latter is the most preferred mechanism in measuring compliance. ${ }^{102}$

\footnotetext{
99 J O O (also known as J M) v Attorney General \& 6 others [2018] Eklr.

100 Chenwi, Lilian, Monitoring the Progressive Realisation of Socio-economic Rights Lessons from the United Nations Committee on Economic, Social and Cultural Rights and the South African Constitutional Court. Community Law Centre, University of the Western Cape Research paper written for Studies in Poverty and Inequality Institute, 2010: 5

101 Chenwi, Lilian, Monitoring the Progressive.

102 Chenwi, Lilian, Monitoring the Progressive.
} 


\section{CONCLUSION}

In conclusion, though Kenya has made tremendous progress in the adjudication of SER, many challenges still exist. This is an indication that progressive realization of SER is still work in progress, and these challenges would have to be addressed before being anchored into mainstream human rights, just like political and civic rights. For a start, it is generally agreed that the realization of all economic, social, and cultural rights will not be achieved in a short period of time. ${ }^{103}$ Therefore, States are responsible for the progressive realization of the rights in question and need to make every effort towards fulfilling that goal. This is despite the wisdom behind the enforcement of SER as their self-reinforcing nature, especially in societies that are undergoing a transformation. The case for enforcement is hinged on the idea that continued violation has a direct and negative impact on key values enshrined in international, regional, and even domestic instruments such as equality, human dignity, and discrimination. In that sense, the transformative agenda of the Constitution cannot be met unless vices of inequality and extreme poverty are addressed. Therefore, the conversation about progressive realization is a good starting point.

The Courts in Kenya have similarly struggled to find adequate remedies anytime SER is violated. Nevertheless, courts have developed ingenious ways of developing new remedies that speak directly to these violations, while expanding and giving meaning to old ones such as prohibitory and mandatory order. Other developments in Kenya in using progressive realization as a standard to implement equality and non-discrimination beyond SER is an indication that indeed the law is an instrument of transforming society. Though the scope and content of SER and its remedies have not been clearly articulated and are still progressive in nature; it is incumbent upon the state and the judicial system to guarantee that the socioeconomic rights of citizens are protected and enforced.

In a developing country like Kenya, where the need to promote the dignity of the poor, vulnerable and marginalized is of great essence and the need to balance

${ }_{103}$ CESCR, General Comment no. 3, para. 9. 
the limited resources, SER remedies require to be translated and interpreted in a manner that provides tangible benefits. Some of the remedies from the courts have compelled the government to take certain measures that ensure that the SER is protected and realized, damages and compensation have been awarded, and in some instances, courts have required the government to take legislative steps that ensure SER are realized.

\section{BIBLIOGRAPHY}

Additional Protocol to the European Social Charter Providing for a System of Collective Complaints (1995).

African Charter on Human and Peoples' Rights, OAU Doc. CAB/LEG/67/3 rev. 5, 21 ILM 58 (1982), ratified by 53 member States of the African Union (AU). African Charter on the Rights and Welfare of the Child (1990). Ratified by Kenya on 25 July 2000.

Ahmed, Dawood and Elliot Bulmer. Social and Economic Rights International IDEA Constitution-Building Primer 9, $2^{\text {nd }}$ Ed. Stockholm: International Institute for Democracy and Electoral Assistance, 2017.

Bantekas, I and Oette.L. International Human Rights Law and Practice 2nd ed. Cambridge: CUP, 2016.

Cahill-Ripley, A and Hendrick. Economic, Social, and Cultural Rights and Sustaining Peace: An Introduction. London: Friedrich-Ebert-Stiftung, 2018.

Centre for Rights Education and Awareness (CREAW) and 8 others v Attorney General \& Another. Petition no. 207 \& 208 of 2012, [2012] eKLR (CREAW case).

Center for Economic and Social Rights. The Universal Periodic Review: A Skewed Agenda? Trends analysis of the UPR's coverage of Economic, Social and Cultural Rights. New York: CESR, 2016.

Chenwi, Lilian. "Monitoring the Progressive Realisation of Socioeconomic Rights: Lessons from the United Nations Committee on Economic, Social 
and Cultural Rights and the South African Constitutional Court." Research paper written for Studies in Poverty and Inequality Institute, Community Law Centre, University of the Western Cape, 2010.

Federation of Women Lawyers Kenya and Others v The Attorney General and Others, High Court Petition No. 102 of 2011.

Ferraz, Octavio Luiz Motta. "Harming the Poor Through Social Rights Litigation: Lessons from Brazil.” Texas Law Review 89 (2011).

Government of the Republic of South Africa and Others v Grootboom and Others, 2001 (1) SA 46 (CC).

John Harun Mwau \& 3 Others v Attorney General \& 2 Others the Court, High Court Petition no. 123 of 2011.

John Kabui Mwai and Others v The Attorney General and 2 others, High Court of Kenya at Nairobi, Petition No. 15 of 2011.

Kenya Society for the Mentally Handicapped (KSMH) v Attorney General and Others. High Court Petition No. 155A of 2011 (Kenya Society for Mentally Handicapped case).

Kondo, T, Kondo. "Socioeconomic Rights in Zimbabwe: Trends and Emerging Jurisprudence." African Human Rights Law Journal 17 (2017).

Landau, David. “The Reality of Social Rights Enforcement.” Harvard International Law Journal 53, no. 1 (2012).

Liebenberg, S. Socioeconomic rights: Adjudication under a Transformative Constitution. Pretoria: Juta and Company Ltd, 2010.

Mathew Okwanda V Minister of Health and Medical Services \& 3 others, Petition 94 of 2012.

Menell, Natasha G. "Judicial Enforcement of Socioeconomic Rights: A Comparison Between Transformative Projects in India and South Afric." Cornell International Law Journal 49 (2016). 
Merali, I \& V Oosterveld. Giving Meaning to Economic, Social and Cultural Rights. Philadelphia: University of Pennsylvania Press, 2011.

Minister of Health and Others v Treatment Action Campaign and Others, no. 2, 2002 (5) SA $721(C C)$.

Moyo, Khule Kani. The Jurisprudence of the South African Constitutional Court on socioeconomic rights, in Foundation for Human Rights, Socioeconomic Rights: Progressive Realisation? Johannesburg: Foundation for Human Rights, 2016.

Ngang, Carol C. "Judicial Enforcement of Socioeconomic Rights in South Africa and the Separation of Powers Objection: The obligation to Take Other Measures." African Human Rights Law Journal 14, no. 2 (2014).

Occupiers of ${ }_{51}$ Olivia Road, Berea Township and 197 Main Street, Johannesburg v City of Johannesburg and Others, 2008 (3) SA 208 (CC).

O'Connell, Paul."The Death of Socio Economic Rights." Modern Law Review 74, no. 4 (2011).

PAO v. AG, High Court of Kenya, Petition No. 409 of 2009.

R v Askov [1990] 2 SCR 1199.

Ray, Brian. "Engagement's Possibilities and Limits as a Socioeconomic Rights Remedy." Washington University Global Studies Law Review 9, (2010).

Satrose Ayuma and 11 Others v The Registered Trustees of the Kenya Railways Staff Retirement Benefits Scheme and 2 Others. High Court of Kenya, Petition No. 65 of 2010.

Schachter v Canada [1992] 2 SCR 679, [63].

Scott, Craig and Philip Alston "Adjudicating Constitutional Priorities in a Transnational Context: A Comment on Soobramoney's Legacy and Grootboom's Promise." S.AFR. J. ON HUM. RTS 16 (2000).

Schmid. E. Taking Economic, Social and Cultural Rights Seriously in International Criminal Law. Cambridge: Cambridge University Press, 2015. 
Ssenyonjo, M. "The Influence of the International Covenant on Economic, Social and Cultural Rights in Africa." Neth Int Law Rev 64, (2017): 259-289.

Soobramoney v Minister of Health (Kwazulu - Natal), 19981 SA 765 (CC). 41.

Stein, T. "Constitutional Socio-economic Rights and International Law: You are not Alone." PER, / PELJ 16, no. 1 (2013).

Supreme Court Advisory Opinion, In the Matter of the Principle of Gender Representation in the National Assembly and the Senate, Supreme Court of Kenya, Advisory Opinion Application 2 of 2012, paras 1-2 \& 27-30 (Gender Rule Advisory Opinion).

The City of Johannesburg Metropolitan Municipality v Blue Moonlight Properties. 39 (Pty) Ltd and Another 2012 (2) SA 104 (CC).

The Constitution of Kenya 2010.

The Constitution of Kenya (Protection of Fundamental Freedoms) Practice and Procedure Rules, 2013, Legislative Supplement No. 47, 28 June 2013, Kenya Gazette Supplement No. 95, Rule 3(2).

The Constitution of South Africa, 1994.

The East African Centre for Human Rights. A Compendium on Economic and Social Rights Cases under the Constitution of Kenya 2010. Nairobi: EACHR, 2015.

Trispiotis, I. "Socioeconomic Rights: Legally Enforcable or just Aspirational." Opticon 8 (2010).

UNTS. "Convention on the Elimination of All Forms of Discrimination against Women 1979." Treaty Series 1249, Entry into force 3 September 1981, https:// treaties.un.org/doc/Publication/UNTS/Volume\%201249/v1249.pdf.

UNTS. "Convention on the Rights of Persons with Disabilities 2006." Volume 2515, entry into force 3 May 2008.

UNTS. "UN Convention on the Rights of the Child 1989." UNTS 1577, entry into force 2 September 1990. 
UNTS. "International Covenant on Civil and Political Rights, General Assembly of the UN on 19 December 1966." Res. 2200A, U.N. GAOR, 21st Sess U.N. Doc. A/RES/220o, entered into force Mar. 23, 1976, hereinafter ICCPR.

U.N. Econ. \& Soc. Council [ECOSOC], Comm. on Econ., Soc. \& Cultural Rights. "Report on the Fifth Session, Supp. No. 3, Annex III, 10, U.N. Doc. E/1991/23." 1991.

Universal Declaration of Human Rights (UDHR) adopted 1o December 1948.

Woolman, S and H Botha. "Limitations." In Constitutional Law of South Africa and ed, edited by S Woolman et al. Juta\& Co., Original Service, 2006. 